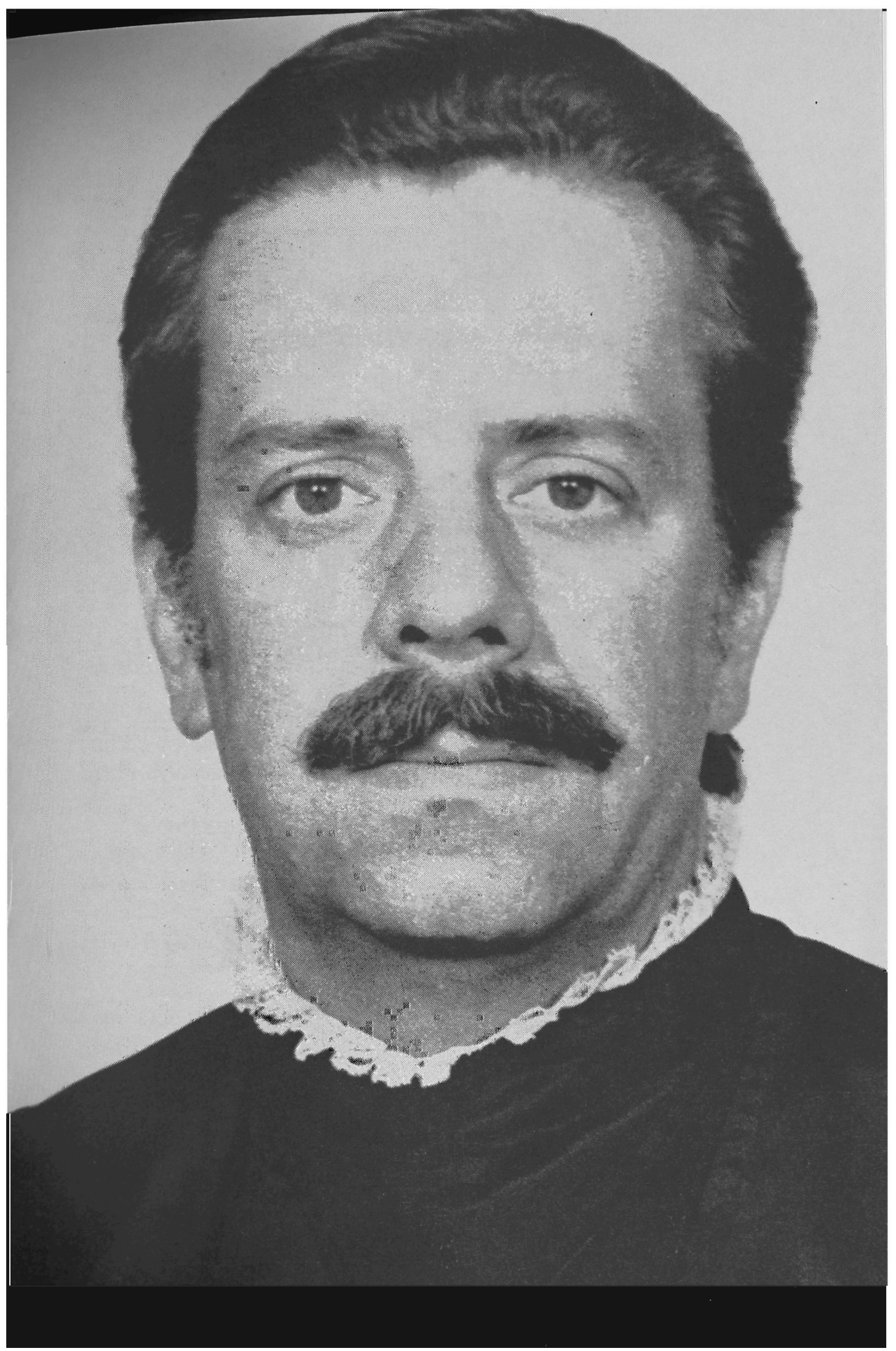


José Ignácio Botelho de Mesquita,

Professor Titular de Direito Processual Civil, 


\section{José Ignácio Botelho de Mesquita, Titular de Direito Processual Civil.}

\section{A Redação}

José Ignácio Botelho de Mesquita nasceu nesta capital aos 11 de julho de 1935. E filho do Dr. Paulo de Mesquita

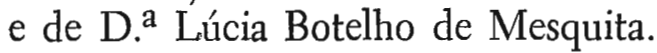

Fez o curso: ginasial e clássico no Colégio São Luís, desta cidade, de 1947 a 1953.

Em 1954 ingressou na Faculdade de Direito da Universidade de São Paulo, onde concluiu o curso de Ciências Jurídicas e Sociais, em 1958.

Continuou os estudos de Direito na Faculdade de Direito de Madrid, com bolsa concedida pelo Ministério das Relações Exteriores da Espanha. Naquela Universidade fez os estudos superiores de Direito Processual, Direito Administrativo, e Direito Civil, durante os anos de 1959 e 1960.

Retornando ao Brasil, iniciou o curso de Especialização em Direito Processual Civil nesta Faculdade, concluindo-o em 1962.

Em 1963, obteve o título de doutor em Ciências Jurídicas e Sociais, em virtude de aprovação em concurso para a Livre Docência de Direito Judiciário Civil, hoje Direito Processual Civil. 
Após esse concurso, dedica-se intensivamente à docência da matéria, nesta Faculdade, onde também lecionou por vários anos, Direito Civil.

Além da atividade docente, dedica-se a outras paralelas. Profere Conferências e organiza Seminários sobre temas de sua especialidade, em importantes centros jurídicos da Capital, do Interior e outros Estados. Participa do Primeiro Congresso Nacional de Direito Processual Civil, realizado em São Paulo e Campos do Jordão, em 1965, para exame e discussão do Anteprojeto do Código de Processo Civil.

Exerce a advocacia nesta Capital.

Participa da Comissão designada pelo Governador do Estado, em 1967, para elaborar o Anteprojeto do Código Judiciário do Estado.

Em 1973, por concurso de títulos, obtém o título de professor adjunto do Departamento de Direito Processual.

E membro do Instituto dos Advogados de São Paulo e do Conselho Consultivo do Instituto Jurídico da Associação Comercial deste Estado.

Em razão do nível científico de suas aulas e da dedicação aos seus alunos, fiel aos ideais que o seu discurso de posse revela, mereceu ser distinguido com sua escolha para patrono ou paraninfo de praticamente todas as turmas de bacharelandos que lecionou.

Os trabalhos que publicou, estritamente vinculados à matéria de sua especialidade, compõem sua bibliografia, essencialmente doutrinária. 


\section{Bibliografia .}

1. A autoridade da Coisa Julgada e a Imutabilidade da Motivação da Sentença, São Paulo, 1963, tese apresentada ao concurso para obtenção do título de Livre Docente;

2. A "Causa Petendi" nas Açōes Reivindicatórias, "in" Revista de Direito Processual Civil, São Paulo, 1967, ano III, v. 6, p. 183 e segs.

3. Da Propositura da Ação de Mandado de Segurança, "in" Revista dos Tribunais, São Paulo, 1970 , v. 418 , p. 19 e segs. - preleção proferida na Faculdade de Direito da Universidade de São Paulo, no ciclo de conferêncla sobre o Mandado de Segurança, organizado pelo Instituto de Direito Público desta Faculdade em conjunto com o Instituto dos Advogados de São Paulo.

4. Trabalhos publicados na seção de Jurisprudência da Revista de Direito Mercantil, Industrial, Econômico e Financeiro, São Paulo:

a) Sobre a Aplicabilidade do Principio da Imediatidade no Processo Falimentar, "in" Revista cit., 1971, ano X, v. 2, p. 63 e segs. - Comentário a acórdão.

b) Sobre o Recurso Cabivel da Decisão que Homologa pedido de Desistência de Concordata Preventiva, "in" Revista cit., 1972, ano XI, v. 6, p. 74 e segs. - Comentário a acórdâo.

c) Sobre a Inteligência do n. I do Artigo $2 .^{\circ}$ da Lei de Falências, "in" Revista cit., 1972, ano XI, v. 7, p. 81 e segs. - Comentário a acórdão.

5. Da Liquidez Suficiente para Requerer a Falência, "in" Revista de Direito Mercantil, cit., 1972, ano XI, v. 7, p. 47 e segs.

6. Da Ação Civil, Editora Revista dos Tribunais, São Paulo, 1973, - tese para o concurso de Professor Titular de Direito Processual Civil da Faculdade de Direito da USP.

\section{A Titularidade e a Recepção no Doutoral.}

Em brilhante concurso de títulos e provas, apresentando a tese Da Ação Civil, o professor José Inácio Botelho de Mesquita, aprovado por unanimidade, obtém a titularidade de Direito Processual Civil, vaga pela aposentadoria do professor Moacyr Amaral Santos.

Nomeado a 15 de novembro de 1975, é recebido solenemente pela Congregação dos Professores aos 22 de abril deste ano. A sessão realizada no salão nobre foi presidida pelo Senhor Diretor, Frofessor Doutor Ruy Barbiosa Nogueira, que 
designou os professores Joaquim Canuto Mendes de Almeida, Miguel Reale e Goffredo da Silva Telles Júnior para introduzirem o novo titular no recinto.

Foi, então, saudado pelo professor Goffredo da Silva Telles Júnior que, de improviso, enalteceu a personalidade e a obra do novo titular, em discurso publicado a seguir

\section{Discurso de Saudação de Goffredo da Silva Telles Júnior*.}

Estamos em fins de abril. Pleno outono. Logo virá o inverno. Mas sei que a primavera chegou nesta nossa Academia.

José Inácio Botelho de Mesquita.

Vejamos se consigo, em' rápidas pinceladas, revelar a personalidade do Professor que agora atinge o pináculo da carreira docente e ingressa em nossa Congregação.

Seu avô paterno costumava dizer que o título de Professor de Direito da Academia do Largo São Francisco era o mais alto grau que alguém poderia alcançar na vida.

Esse avô era bacharel por nossa Academia. Chamava-se Ignácio Mesquita. Era de Itu e foi Republicano histórico.

As palavras do avô, o pai as repetia em casa.

O pai, Paulo de Mesquita, também se formou nesta Academia e pertenceu ao "14 de julho", como combatente em 1932. Casou-se com Dona Lúcia, da tradicional família Arruda Botelho, de São Carlos.

O avô materno, José de Arruda Botelho, natural de São Carlos, fazendeiro de café, pertencia a uma cepa de monarquistas, entre os quais pontificaram alguns dignatários da no-

*. Este discurso foi apanhado pelo serviço de gravação da Faculdade de Direlto. 
breza imperial, como por exemplo, o Conde de Pinhal, fundador de São Carlos, o Barão de Dourados e o Visconde de Rio Claro. Mas, curiosamente, ele próprio sempre foi um republicano convicto.

Adivinho, sem dificuldade, o espírito que certamente reinou no ambiente doméstica do menino José Ignácio, filho e neto dessa gente.

Entre os que, neste momento, me ouvem, deve haver muitos que sabem, por experiência própria, o que é ser filho de quem passou pelas Arcadas, e bem podem imaginar o que é ser não somente filho, mas também neto de antigos alunos da velha Academia do Largo de São Francisco.

Uma certa mentalidade, um modo característico de pensar, não sei como dizê-lo: um amor quase cego pela Liberdade; uma fé quase religiosa na Lei e na Justiça; a chama de uma sempre acesa cordialidade, de uma permanente vontade de compreensão, de um amor constante pelo ser humano; tudo isto, e ainda um apego afetivo pela Velha Academia; um orgulho insopitável por tudo quanto fizeram pelo Brasil os filhos de nossa Escola - tais são algumas das causas da atmosfera sentimental numa casa de verdadeiros bacharéis da São Francisco.

O Direito já é, em si próprio, a disciplina da convivência. A Ciência do Direito, por sua vez, é a chave, a Ciência-Chave da Comunicação humana. E esta Academia, pela sua tradição de luta, pela sua vibração, por sua extrema sensibilidade, pelo seu vibrante idealismo, pelos seus sacrifícios, por todo o seu modo de ser, se constitui numa escola de vida. Isto, aliás, é o que faz a sua grandeza. Aqui dentro uma humanidade em miniatura palpita, com seus problemas, suas esperanças, suas a'egrias, suas decepções. Antes de ser uma Escola de Direito, nossa Faculdade é uma Escola de Vida. É evidente que as duas expressões quase coincidem, em seu sentido, uma com a outra. Pois o Direito há de ser um reflexo da vida. 
A Casa do Doutor Paulo de Mesquita recebeu, de certo, o misterioso influxo desta Escola. E foi nessa casa que José Ignácio Botelho de Mesquita começou a tomar consciência das coisas do mundo.

Ignácio de Mesquita nasceu em' julho de 1935, na cida'de de São Paulo. Nas pegadas do avô, fez o ginásio e o curso clássico, no Colégio São Luiz.

Sua formação moral foi extremamente severa. Toda a sua juventude esteve marcada pela obstinada obediência a princípios rígidos. "Excessivamente rígidos", segredou-me ele um dia.

A cultura, em alto sentido, ele principiou a vislumbrá-la no curso clássico, quando os padres ergueram, diante de seus olhos espantados, os primeiros véus da filosofia.

Nessa época, o nazismo tenebroso obscurecia os céus da terra. No Brasil, um anseio de legalidade forcejava para romper os quadros do regime de Getúlio Vargas. O cataclisma da segunda guerra mundial e a tragédia da bomba atômica acabaram devastando o coração da juventude.

No espírito do ginasiano Ignácio Mesquita, já se instalara o horror por todos os governos de força, fossem eles comunistas, nazistas ou fascistas.

Eu creio, sinceramente, que Ignácio Mesquita, nesse tempo, ainda não saberia definir a democracia. $\mathrm{O}$ que ele certamente sabia, vivendo no clima de sua casa, era que todo governo não escolhido pelo povo era governo que se impunha a si próprio, pela força das armas, sendo, portanto, um governo ilegítimo, talvez ilegal e quase sempre intolerável. O que ele sabia, certamente, era que nenhum governo podia se declarar proprietário exclusivo da verdade, sob pena de conduzir a nação às hecatombes totalitárias. 
Ali estava, diante dele, a ditadura de Vargas, que o pai lhe desorevia com a imaginação de um combatente de 32. Eu presumo que seu pai lhe deve ter falado sobre a censura odiosa, feita pelos donos da "sabedoria", a impedir a manifestação das idéias; sobre cassação do parlamento nacional e das assembléias legislativas, destruindo as frágeis, mas únicas bases então existentes, da legitimidade das leis; e sobre a nefanda tortura, nos calabouços da ditadura, a destroçar qualquer esperança nos escalões do poder.

Em 1954, Ignácio Mesquita obteve uma bela terceira colocação nos exames vestibulares, e matriculou-se na Faculdade de Direito.

Ele foi meu aluno no $1 .^{\circ}$ ano. Guardo, até hoje, a lembrança de sua figura de estudante. Já naquele tempo, ele tinha uma expressão grave, como a de alguém que está preocupado com os problemas da humanidade. Era moço muito bem educado, muito atento às aulas. Sua fisionomia séria, ele não somente a mantinha na classe, mas também nos corredores e no patio. Séria, sim, mas um rosto que não se negava a logo abrir-se, num claro e doce sorriso, ao mais leve gesto, à mais simples palavra que lhe dirigisse o professor.

Durante os dois primeiros anos da Faculdade, ele fez o CPOR. Foi eleito orador de sua turma. E depois estagiou na Base Militar de Ponta Porã, onde completou seus conhecimentos sobre as Forças Armadas. Conhecimentos estes que, segundo ele mesmo me disse, lhe foram muito úteis, para seus julgamentos futuros, sobre certos fatos da política brasileira.

Recebeu seu grau de Bacharel em 1958. Ele já sabia advogar, porque vinha trabalhando com afinco, num grande escritório de São Paulo.

Uma vez formado, obteve uma bolsa de estudos, concedida pelo governo da Espanha. Foi doutorar-se na Universidade de Madri. Logo após sua chegada nessa Capital, 
foi logo eleito Presidente da Associação dos Universitários Brasileiros na Espanha.

Procurou Legaz y Lacambra, para estudar Filosofia do Direito. Mas, como todos nós sabemos, o grande mestre se ausentara da Espanha. Então, procurou o professor Jayme Guasp, que desfrutava de grande reputação entre os alunos. Este mestre era professor de Processo. E assim foi que Ignácio Mesquita começou a estudar Processo, quase por acaso.

Um extraordinário acontecimento marcou, nessa época, a vida de Ignácio Mesquita: a Espanha se revelou a ele, exercendo o seu fascínio sobre o espírito do jovem bacharel. A Espanha medieval e moura; amorosa, arrebatada; petulante, heróica e autêntica. O que, sobretudo, deve ter impressionado Ignácio Mesquita, foi o incêndio pela Liberdade, abrasando as consciências espanholas; incêndio que se propagou para a sua alma generosa, ainda em formação.

Uma convicção se firmou em seu espírito: a da influência que um, regime político pode ter na formação da mocidade. O regime da Espanha havia mutilado a inteligência da juventude, e a vida universitária se apresentava amorfa, apática, anestesiada, desligada da política do país, desinteressada pelos destinos do mundo.

Em setembro de 1960, voltou para 10 Brasil. Seu espírito estava preparadio para enfrentar a luta da vida. Ele trouxera da Espanha uma resolução definitiva. Resolvera ser sempre ele próprio, isto é, um homem autêntico. Um dia, ele me perguntou se um homem autêntico não tinha um pouco de Dom Quixote. Eu lhe quis dar uma resposta sincera e disselhe que o progresso espiritual da humanidade é uma arremetida constante contra moinhos de vento. Dom Quixote se viu derrotado pelos seus moinhos de vento. Mas Dom Quixote era um só. Quando se formam batalhôes de Dom Quixotes, a humanidade dá um passo para a frente. 
Nos anos de 1961 e 1962, ele fez o curso de especialização na Faculdade de Direito. Ao terminá-lo, o Professor Luiz Eulálio Bueno Vidigal o chamou, incentivando-o a prosseguir nos seus estudos e a ingressar na carreira docente da usp. Com isto, o Professor Vidigal demonstrou a sua rara sensibilidade de professor, ao descobrir, em seu discípulo, todas as potencialidades que nele existiam.

Em dezembro de 1963, Ignácio Mesquita fez o seu concurso de Livre-Docente de Direito Judiciário Civil. Sua tese se intitulava: A Autoridade da Codisa' Julgada e a Imutabilidade da Motivação da Sentença.

Assisti às provas deste concurso e quero dar a minha opinião sobre as mesmas. Na prova de defesa de tese, o candidato demonstrou tanta calma e segurança que desde logo ficou patenteada a sua competência na disciplina em concurso. Na prova didática, Ignácio Mesquita soube manter-se na difícil linha que caracteriza o professor acostumado a dissertar perante assembléias heterogêneas. Como todos sabem, a prova didática é extremamente delicada, uma vez que uma exposição demasiado singela pode levar a comissão julgadora a pensar que a matéria explicada não tem qualquer interesse, por ser do conhecimento de todos; e que uma exposição de alta cultura pode levar a comissão julgadora à convicção de que a matéria explicada não tem condições de ser entendida por uma classe de alunos. Sendo aprovado, Ignácio Mesquita obteve o título de Livre Docente desta Faculdade.

Começou a lecionar em 1964. Lecionou também Direito Civil, de 1965 a 1968.

Logo se manifestaram os traços característicos do novo professor. Creio que os principais são os seguintes. Primeiro, Ignácio Mesquita soube estabelecer um ótimo relacionamento entre ele e seus alunos, relacionamento direto e estreito, 
não somente na classe de aula, mas também fora dela. Segundo, a sua independência intelectual: ao expor os pontos do programa demonstrou a sua efetiva autonomia de convicções. Finalmente, a clareza das suas aulas lhe deu imediatamente a reputação de excelente comunicador de idéias.

Ele bem entendeu a alta missão de um professor universitário. O seu papel não era apenas o de informar, mas também o de formar os seus discípulos. O seu papel não era apenas o de levar aos alunos os seus próprios conhecimentos sobre a sua disciplina, mas sobretudo o de despertar o amor pelo estudo da sua disciplina.

Tenho para mim que a maior vitória de Ignácio Mesquita foi aquela que obteve na difícil prova de classe, a prova de todos os dias, ao dar as suas aulas do currículo. Pois conquistou ele, sem demюra, a admiração e a estima de seus alunos. A prova do que acabo de afirmar, encontro-a no seguinte: foi eleito tres vezes patnono dos bacharelados da Academia - turmas de 1966, 1968 e 1969, sendo que em 1966, ele ainda estava no segundo ano da carreira docente. $\mathrm{E}$ foi eleito duas vezes paraninfo, em 1972 e 1974, sendo que em 1972, ele ainda era Livre-Docente.

Assim se vai delineando a figura do Professor Ignácio Mesquita. Exato cumpridor dos seus deveres, extremamente competente em sua disciplina, querido de seus alunos, modelo de integridade moral e de compostura.

Suas publicações começaram a vir a lume: A Causa Petendi nas Ações Reivindicatórias, Da Propositura da Ação de Mandado de Segurança, A Aplícabilidade do Princípio da Imediatidade no Processo Falimentiar, O Recurso Cabível da Decisão que Homologa Pedido de Desistência de Concordata Preventiva, A Inteligência do n. ${ }^{\circ} 1$ do Art. $2 .^{\circ}$ da Lei de Falências, Liquidez Suficiente para Requerer a Falência. 
Realizou cursos, seminários, conferências, em faculdades diversas, centros de estudos e institutos especializados, tanto em São Paulo como em outros Estados.

Em junho de 1974, fez o concurso para o cargo de Professor Titular do Departamento de Direito Processual. Concorrendo com dois eminentes juristas de São Paulo, obteve, com toda justiça, or primeiro lugar. Apresentou a tese $\mathrm{Da}$ Ação Civil. Não é um livro de vastas dimensōes, mas constitui uma curiosa monografia. A meu ver essa obra é um marco na evolução das chamadas teorias processuais "concretas" Note-se que ela se opõe corajosamente à teoria de Liebman, teoria esta que, segundo a opinião de nosso professor, trouxe grandes benefícios, mas contribuiu para esterilizar a doutrina brasileira.

Em dez anos, Ignácio Mesquita subiu os degraus da carreira docente. Conquistou lugar de grande relevo. E membro do Instituto dos Advogados de São Paulo; foi membro da Comissão do Governo do Estado de São Paulo para elaboração do anteprojeto do Código Judiciário do Estado. Pertence ao Conselho consultivo do Instituto Jurídico da Associação Comercial. Figurou duas vezes, como jurista, na lista tríplice para o cargo de Juiz do Tribunal Eleitoral do Estado.

$O$ que não pode ser esquecido é que Ignácio Mesquita é advogado militante, exercendo ativamente aquele tipo de advocacia que eu chamaria de advocacia artesanal. Ele é, de fato, um advogado artesão, isto é, um advogado que, sozinho, cuida integralmente de cada causa, como se cada causa fosse a causa de sua vida.

Vejo em Ignácio Mesquita duas vocações absolutas: a vocação para a docência universitária e a vocação para a advocacia. Estas vocações constituem, em verdade, chamamentos de sua natureza autêntica. O termo "vocação", de "vocatio", "vocare", chamar, designa uma atração natural, ou seja, uma inclinação por força da natureza da pessoa. Falsas vocações 
se manifestam às vezes, como quando uma pessoa exerce uma função por achá-la atraente ou bela, mas não por ser arrastado a executá-la em virtude de uma tendência espontânea. A verdadeira vocação é um constrangimento da natureza. Ninguém se surpreenda com a apnoximação que acabo de fazer entre os termos vocação e constrangimento.

Lembro-me do diálogo entre Juliano e uma voz desconhecida, numa célebre página de Ibsen. Juliano pergunta: "Qual é minha vocação?" A voz lhe responde: "A vocação de teu querer." Juliano pergunta: "Que devo eu querer?". A voz lhe responde: "Aquilo a que és constrangido."

Mas como descobrir a vocação? Esta pergunta, Rilk a responde ao jovem poeta: "Não há senão um caminho. Procure entrar em si mesmo. Investigue o motivo que o manda escrever, examine se esse motivo estende suas raízes pelos recantos mais profundos de sua alma; confesse a si mesmo: morreria, se me fosse vedado escrever? Isto acima de tudo: pergunte a si mesmo, na hora mais tranqüila de sua noite: "Sou mesmo forçado a escrever?"

Vocação é essa força interna, íntima. E esse constrangimento inerente.

A vida de Ignácio Mesquita é o sinal e o testemunho de sua vocação. $O$ que o qualifica é a sua autenticidade. Ele vive o que pensa. Não sei se posso fazer elogio maior a um homem. Não sei se haverá vida melhor do que a daquele cuja existência reflete o seu pensamento.

Houve uma hora de trevas nesta Faculdade. Todos ainda se lembram dela. Um vento levantino crestara o chão de nossa Academia. Nas trevas, ouvia-se a voz iluminada de Rocha Barros: "Mais vale acender uma vela do que maldizer a escuridão"

Ignácio Mesquita acendeu a sua vela. Outras velas também se acenderam. Mais uma vez, ficou patente que "não é matando passarinhos que se vai acabar com a primavera". 
Ignácio Mesquita tem apenas quarenta anos de idade. Está na flor da vida. Mas há velhos de dezoito anos e há moços de oitenta. Ignácio Mesquita é daqueles que sabem continuar moços pela vida afora. Ele sabe que a mocidade também é um estado de espírito. E que a mocidade de espírito consiste na abertura da inteligência para as novas paisagens de cada dia.

É doce o enlevo de reler os velhos livros, queridos livros de ontem, de hoje, de sempre. Mas é um arrebatamento o livro que abre, diante dos olhos do espírito, um caminho imprevisto, um horizonte insuspeitado, talvez um universo diferente.

O segredo da eterna juventude está na sabedoria de nascer de novo em cada madrugada.

\section{Quem é Ignácio Mesquita?}

Ele é o professor por vocação, autêntico, íntegro, sincero, fiel em todos os sentidos, jurista na melhor acepção do termo, espírito aberto para a cultura dos novos tempos, valoroso, intrépido. Antifacista e anti-comunista, mas homem do presente e do futuro. Ignácio Mesquita é filho autêntico desta Academia.

Estamos em fins de abril. Pleno outono. Logo virá o inverno. Mas eis que a primavera já chegou nesta nossa Academia.

\section{O Novo Titular Profere seu Discurso de Posse.}

Após a saudação de Goffredo Telles Junior, o novo titular profere seu discurso de posse. Agradece as palavras do representante da Congregação e expõe seu ideal de Professor Universitário das Arcadas: a "integração de todos num corpo único" para a realização de um programa, cujas metas básicas sejam a liberdade, a cultura e o Direito.

No momento que, perante os meus pares, me vejo investido, em ato solene, da condição de professor titular de Direito 
Processual Civil, e com ela das responsabilidades inerentes ao meu cargo, quero reafirmar, ante esta augusta assembléia, o meu compromisso para com esta Faculdade, de envidar o melhor dos meus esforços para manter-me, sem vacilações, no mesmo caminho que me trouxe até aqui.

Por haver merecido a confiança dos meus mestres, especialmente a dos que hoje me honram com a sua presença, considero que a via escolhida guardou a necessária conformidade com os caminhos que a História apontou para esta Faculdade, a gloriosa e imperecível Academia de Direito do Largo de São Francisco.

Hoje, contudo, mais do que nunca, tenho a consciência, informada de um conhecimento todo de experiências feito, que nada é mais difícil, na idade madura, que dar conseqüência às idéias semeadas ao longo dos anos mais jovens. Na medida em que os anos passam, tende a razão a espalhar seu frio manto, sobre as lavas ainda quentes do estado de permanente erupção, em que vivemos enquanto moços.

E tempo, portanto, de recolher as experiências vividas, antes que esfriem, iluminá-las à luz do momento atual, e extrair delas alguma contribuição, que possa servir de ponto de partida para novos e mais árduos cometimentos.

Os que me acompanharam nesta Faculdade sabem que fui honrado com a amizade de muitos de meus colegas; sabem igualmente que, nos momentos difíceis, tive sempre ao meu lado, aliados firmes e corajosos, que repartiram comigo as agruras dos ventos e o fragor das tempestades, e com quem hoje reparto as alegrias e as honras da vitória, do mesmo modo como partilhei com eles do entusiasmo pelas vitórias que alcançaram. Mas sabem também que, fundamentalmente, na maior parte do meu tempo, voltado quase que apenas para os meus alunos, trajetei solitariamente no círculo de meus colegas, professores. 
Esta atitude, que é também a de muitos dos nossos, mergulha suas raízes, em última análise, na compreensão mítica desta Faculdade, gerada pelo seu destino, a um só tempo heróico e poético, que a todos, alunos e professores, igualmente e irresistivelmente nos empolga. Sob o influxo poderosíssimo desta visão perturbadora, que nos é transmitida pela tradição de que se emprenham nossas arcadas, vemos os nossos passos conduzidos freqüentemente, antes pela nossa ligação individual com as crenças que fizeram a grandeza desta Casa, que para a consideração dela, enquanto corpo de homens, em si mesmos díspares, tanto no entendimento e na sensibilidade, como na formação cultural e espiritual, unidos apenas por uma igual vocação para o estudo e o ensino do Direito.

Os que conhecem a história desta Casa sabem, contudo, que ela nem sempre foi poética ou heróica, como nem sempre foi santa. Sabem-no também, que o território livre de São Francisco, nem sempre foi livre, e hoje como no passado, temos disso o exemplo e a consciência.

Ora, ao cabo de mais de vinte anos vividos sob estas arcadas, como aluno ou como professor, e a elas dedicados até os extremos de minhas possibilidades pessoais, posso me permitir ponderar que nada satisfaz menos às necessidades desta Faculdade, nem mais contribui para que ela se desvie de seu destino histórico, que a errônea conceituação de sua própria natureza, de seu peculiar modo de ser, e dos objetivos que ela verdadeiramente está preparada para atingir.

A conceituação desta Faculdade como algo de místico, e de suas tradições como alguma coisa que se realiza no presente, pelo simples fato de se ter realizado no passado, pode ocasionalmente gerar homens que sejam poetas, santos ou heróis, mas não conduzirá jamais à união de todos os pretendentes a poeta, santo ou herói, em torno de umi objetivo comum que atenda de fato aos fins mediatos e imediatos que a esta escola verdadeiramente se propõem. 
O que esta Faculdade efetivamente tem, como nota característica, é a sua natureza de entidade votada à execução de um programa que, na sua fundação - conseqüência de nossa independência política de Portugal, nos foi assinado por exigências históricas de nacionalidade, em termos de sobrevivência como Nação livre e soberana. Vem daí o fato de que, nesta Casa, o ensino das leis nunca foi feito apenas pelo ensino das leis, mas pela consciência de que nenhum povo pode ser livre e soberano se não dispuzer de um ordenamento jurídico que lhe garanta esses bens fundamentais; nem poderá dispor de tal ordenamento a nação que não for dotada de um elevado grau de cultura jurídica.

Liberdade, cultura e direito constituem as metas básicas de nosso programa, que se realiza, cotidianamente, por meio do ensino das ciências jurídicas. Daí porque, entrar nesta Casa, como aluno ou professor, é bem mais do que pagar matrícula ou assinar um contrato de trabalho; é tomar partido, é assumir um compromisso de ação, é dispor-se a servir o País naquilo de que ele mais fundamentalmente necessita, - hoje, como no passado: o aprimoramento do Direito e a defesa das liberdades fundamentais.

A menos que consideremos tais bens como supérfluos, a menos que nos convençamos da inutilidade do Direito, seremos sempre forçados, ainda que despidos de qualquer poesia, mas pela simples e natural pressão dos valores fundamentais da sociedade em que vivemos, a reconhecer a existência desse programa, e a sentir-nos obrigados a cumpri-lo.

$E$ evidente, contudo, e a experiência dos anos vividos sob estas arcadas m'o demonstrou à saciedade, que a execução de um tal programa não pode ficar na dependềncia da ação isolada de cada um, eventual e transitória ou ainda que permanente e duradoura. Por tratar-se de um objetivo que transcende a esfera individual de cada um, somente pela nossa reunião num corpo só, organicamente orientado à consecução deste fim, é que poderemos realizá-lo. 
Neste setor, a atividade individual de cada um, ao sabor apenas de suas conviç̧ões pessoais, correrá sempre dois riscos inarredáveis dessa modalidade de ação. $\mathrm{O}$ risco de não satisfazer aos anseios da coletividade mas sim os do agente isolado, e o risco de este atuar contra tais interesses, ainda quando esteja convicto de estar-lhes dando cabal realização.

Creio, portanto, que somente na integração de todos num corpo único, é que lograremos a realização do programa desta Faculdade.

A História, contudo, nos demonstra que tais corpos, por força da sua burocracia interna, tendem sempre à formação de uma ditadura das cúpulas, perdendo-se nos degraus de sua hierarquia todo o ímpeto da força original que lhes deu nascimento.

Ora, uma das alternativas para evitar essa perda de potência e de coesão já foi tentada sem êxito no passado desta escola. Consistiu em restringir o corpo docente quase que só aos professores catedráticos e a uns poucos professores livredocentes. Estes, escolhidos a dedo, mais sob a condição de estrita obediência, que com atenção à sua capacidade de exercer na plenitude as funções reservadas a um mestre de Direito.

Coube ao extraordinário descortino de Luiz Eulálio de Bueno Vidigal, enquanto diretor desta Faculdade, pôr fim a esta opção suicida, que vinha estiolando a Academia e comprometendo irremediavelmente o seu futuro.

Assim que assumiu a Diretoria desta Casa, o professor emérito Luiz Eulálio de Bueno Vidigal, por meio de uma só deliberação, que foi decisiva para os destinos da Faculdade, mudou o curso de sua história. Ordenou ele que se realizassem todos os concursos à livre-docência até então requeridos e cujos requerimentos, em alguns casos, há tempos jaziam nos arquivos desta Academia. 
Transitamos assim, de um momento para outro, de uma situação de asfixiante confinamento para outra de campo aberto, onde se podiam descortinar horizontes amplos e arejados para o futuro desta Faculdade.

Ocorreu, porém, que Luiz Eulálio de Bueno Vidigal deixou prematuramente a Diretoria desta Faculdade. A partir daí, o alargamento e, portanto, a elasticidade da base desse organismo, constituída por inúmeros novos livre-docentes, passou a não se adeqüar à fixidez herdada do sistema anterior. Como não podia deixar de ser, seguiu-se a inevitável confrontação. E a ela a desarticulação, o isolamento, a disperção das forças que deveriam impulsionar a Academia.

Esse processo acentou-se anos após, quando implantou-se entre nós o sistema departamental. Acrescente-se a isto o inevitável desdobramento do processo da abertura que introduziu na Faculdade dezenas e dezenas de docentes voluntários, auxiliares de ensino, assistentes e assistentes doutores, além da constante admissão de novos livres-docentes, que daí por diante não encontrariam mais nenhum obstáculo à realização dos respectivos concursos.

Essa realidade revela, que após havermos vencido uma alternativa, a do confinamento, ingressamos em outra, a da abertura, mas ainda não conseguimos extrair desta última os frutos que já se encontravam latentes na semente em boa hora plantada por seu criador.

Cumpre agora, segundo me parece, realizar um amplo movimento de reunião das forças dispersas, de concentração do esforço comum, de reorganização dessa nova realidade que a Academia ostenta, de modo a construirmos um novo corpo, que não terá naturalmente a consistência monolítica que resultava da proposta inicial e já superada, mas que seja o quanto possível permeável à participação de todos, de modo a evitar que torne a fechar-se sobre si mesmo e acabe por impor-nos o regresso aos erros do passado. 
Nesse sentido, considero que um dos instrumentos básicos para lograr-se essa imprescindível permeabilidade, está no fortalecimento da instituição da livre-docência. Minha experiência pessoal, enquanto livre-docente, que foi talvez uma das épocas mais ricas e felizes de minha existência, demonstrou-me que é nas mãos dos livre-docentes que se concentra a maior soma de conhecimentos sobre os anseios de nossos alunos e sobre as necessidades desta Academia.

O livre-docente, por suas condições peculiares de idade, disposição para o trabalho com os alunos, proximidade maior em temperamento e linguagem com o corpo discente, sensibilidade maior para com as realidades do ensino, por estar mais rente a ela, aliadas, de outro lado, à necessária experiência científica que, hoje, a longa carreira docente the proporciona, é o livre-docente quem poderá colaborar de modo decisivo para que, à desejável união de todos nós em prol da realização de um programa comum, não se alie a indesejável ditadura da burocracia.

Não menos importante nesse processo, e até mesmo imprescindível, parece-me a participação do corpo discente. Os écos da palavra "co-gestão", ainda rugem ameaçadoramente nos ouvidos de muitos de nós, como sinônimo de conflagração. O nome não importa. Importa é relembrar que nos momentos em que esta escola tem sido verdadeiramente grande, alunos e professores sempre estiveram unidos sob os mesmos ideais.

Nessa matéria, colhi ao longo desses anos lições de que me não posso esquecer. Não se verificaram em momentos isolados, mas resultam de um conjunto de experiências que, cada qual a seu modo, cada um dos mestres aqui presentes tam bém deverá ter vivido.

Aprendi que os alunos constituem o nosso mais poderoso aliado quando o nosso trabalho docente dá mostras de eficiên- 
cia; e constituem o nosso mais implacável adversário, quando, ao contrário, nos mostramos deficientes.

O aluno é capaz de confiar integralmente num professor, e capaz, portanto, de prestar-lhe valiosa colaboração, quando percebe que este o dignifica mediante um trabalho honesto, intenso, dedicado e frutífero. Mas com a mesma intensidade é capaz de tudo contra um professor que o desrespeite, impondo-lhe o dever de assistir aulas mal preparadas, de ouvir exposições imprecisas ou insinceras, ou dê mostras de não ter coragem de assumir atitudes definitivas em face dos problemas que lhes sejam propostos.

Por isso, penso que devemos temer menos os nossos alunos e mais os obstáculos que nos impedem de dar-lhes o ensinamento a que têm direito. Dentre eles, o que me parece pior é a política de ensino - que não é nossa mas da qual sofremos os efeitos - de dar preferência ao número em prejuízo da qualidade; política essa pretensamente dirigida a uma assim chamada "democratização do ensino".

Ora, não me parece possível, melhorar o nível do ensino se, de um lado, não dispuzermos da possibilidade elementar de trabalhar com grupos de menor número de alunos e, de outro lado, se não pudermos dispor de maior tempo de aulas. $\mathrm{O}$ direito moderno, não é preciso que eu diga, assumiu tal complexidade, que não pode passar despercebido a ninguém o contra-senso de continuarmos com a mesma estrutura de aulas, que tínhamos, quando à formação de um advogado bastava bem conhecer meia dúzia de Códigos.

Essa estrutura ostensivamente inadequada às exigências da atualidade, nos submete diariamente, alunos e professores, ao drama do desempenho de um trabalho que, por melhor que seja, não nos satisfará integralmente, conduzindo-nos a um violento desgaste, que ao cabo de alguns anos se transforma em desânimo e ceticismo. 
A consequiência não pode ser outra senão o rebaixamento do nível de ensino e o afrouxamento dos critérios de aprovação; um e outro traduzindo-se a final em incentivo para que esta Faculdade tenha de acolher, anualmente, um sem número de alunos, que jamais irão exercer atividades relacionadas com o Direito, que jamais restituirão à coletividade os bens culturais que esta lhes proporcionou, mantendo enfim a nossa Academia, como dizia causticamente Alberto da Rocha Barros, na codição de eterno desaguadouro de vocações indefinidas. E estes alunos de vocação indefinida jamais se unirão ao nosso esforço em prol da Academia.

Contra isto lutei durante todos esses anos, como sei que muitos de meus colegas também lutaram. A criação de novos instrumentos de integração desta Casa na comunidade, que é obra da atual Diretoria, é exemplo edificante desta luta e fruto dessas mesmas preocupações. Nossa luta, porém, travada sem obediência a um sistema mais amplo, sem estar iluminada e aquecida pela integração numa unidade de função, é uma luta de resultados provisórios, de prazo determinado, e por isso mesmo limitados.

Ora, sabidamente, sem qualquer desapreço por outras $\mathrm{Fa}$ culdades de Direito igualmente dignas de nossa melhor consideração, é esta Academia aquela que, por seu rigor na seleção, apresenta dentre todas a possibilidade de dispor do melhor corpo de professores e alunos. Temos a consciência de que, apesar de tudo, hoje como no passado, constituimos a guarda-avançada da cultura jurídica no Estado e no País. Não nos falta, nem nunca nos faltou, amor pelos nossos alunos nem devoção pela causa do Direito.

Se dispomos de tudo isso, não é possível duvidar de que tenhamos à nossa disposição o instrumental necessário, desde que unidos, a enfrentarmos a tarefa que a História nos legou.

Necessitamos, porém, além de uma estrutura adequada, de dispormos de liberdade para formar autênticos juristas. 
Não seremos jamais fiéis ao nosso destino de filhos e mestres desta Academia, se nos limitarmos a erigir uma estrutura docente perfeita apenas para formarmos técnicos em legislação, sem ideal e sem bandeira, prontos para servir a qualquer patrão, e até mesmo aos que reneguem as crenças que nos inspiram, os ideais por que vivemos, o amor ao Direito e à $\mathrm{Li}$ berdade, que sempre informaram a consciência do brasileiro, como Homem e como Nação.

$\mathrm{E}$ quando falo nisto, não me refiro evidentemente à liberdade que cada um, individualmente, exerça na medida de sua coragem e de suas convicções pessoais. Esta será sempre a liberdade deste ou daquele, mas não a da Faculdade, não a da Academia.

E preciso que esta Faculdade, mesmo nos tempos de transição em que vivemos, exerça a mais ampla liberdade para que possa formar homens capazes de discernir entre o Direito e o Arbítrio, entre a Justiça e a Violência.

Nesta matéria, que é matéria jurídica, muito antes de ser política, econômica ou militar, cabe aos órgãos do Poder ouvir a Faculdade, e não esta a eles.

$E$ preciso não perder de vista, que nenhum regime é eterno, por melhor ou pior que ele seja. Precisamente por isto, aqueles que julgam benéficas as restrições por que hoje passamos, têm que estar conscientes do fato elementar de que, quando terminada a vigência do regime atual, eles mesmos serão os primeiros a sair em busca dos homens que sejam capazes de discernir entre Direito e Arbítrio; quando menos fôr, em sua defesa contra outro regime ainda mais tirânico ou mais violento.

E a nós nos cabe a responsabilidade de formar esses homens, sob pena de amanhã virmos nós, e não os ocasionais detentores do Poder, a ser vítimas do julgamento inexorável da História. 
Este julgamento, é bom frizar, não será feito apenas à luz da consciência dos homens. Não será feito a partir de normas de caráter singular ou pessoal, cuja ignorância pudéssemos invocar em nosso benefício. Exatamente para que a ninguém, e muito menos a nós juristas, fosse dado ignorar tais normas, a História as fez gravar em texto escrito, que denominou "Declaração Universal dos Direitos do Homem".

No artigo 26, segundo parágrafo, dessa Declaração, está inscrita a norma pela qual seremos julgados. Ela dispõe que

"A instrução será orientada no sentido do pleno desenvolvimento da personalidade humana e do fortalecimento do respeito pelos direitos do homem e pelas liberdades fundamentais."

A quem quer que nos interpele por causa da observância dessa norma, poderemos responder com as palavras milenares que Sófocles colocou na boca de Antígone; respondeu Antígone, quando Creon lhe perguntou "Não obstante (ser público o édito), ousaste infringir minha lei?":

"Porque não foi Zeus quem a ditou - disse Antígone nem foi a que vive com os deuses subterrâneos

- a Justiça - quem aos homens deu tais normas.

Nem nas tuas ordens reconheço força que a um mortal permita violar aquelas não-escritas e intangíveis leis dos deuses.

Estas não são de hoje, ou de ontem; são de sempre; ninguém sabe quando foram promulgadas.

A elas não há quem, por temor, me fizesse transgredir, e então prestar contas aos Numes.

Bem sei, como não? que hei de morrer um dia mesmo sem decreto teu; e se tombar 
morta antes do tempo, então tanto melhor: para quem, como eu, vive entre tantos males, como não será de só proveito a morte?

Posso parecer-te louca, talvez:

mais louco, porém, é o que me julga louca."

E exatamente porque a nós e só a nós nos cabe a responsabilidade de dar cumprimento àquela norma, é a nós que compete fixar os limites de nossa própria conduta como juristas e como professores de Direito. Como sabemos, por uma tradição muito mais do que secular, que os regimes políticos passam por esta Casa e, nela, só a ciência permanece, esses limites hão de ser sempre os ditados pela ciência e, não, os impostos pela política.

Sem isso, não poderemos sobreviver como Faculdade de Direito.

Tudo isso porém, meus senhores, depende de nós mesmos. Não apenas de cada um, isoladamente, repito, mas do conjunto de todos nós, alunos e professores, posto que dele, e só dele, é que emerge a grandeza desta Academia.

Faço pois meu ingresso à E. Congregação desta Faculdade, imbuído do mais ardente desejo de união e de realização de nossos objetivos comuns. Com este espírito, dirijo minhas saudações a todos, professores, alunos e funcionários desta Casa, desejando a cada um a sua felicidade pessoal e, à nossa amada Academia, vida e vitória para sempre. 